\title{
Amyloid Beta 1-38 Measurement
}

National Cancer Institute

\section{Source}

National Cancer Institute. Amyloid Beta 1-38 Measurement. NCI Thesaurus. Code C103352.

The determination of the amount of amyloid beta protein which is composed of peptides 1 to 38 in a sample. 